\title{
Structure of Vegetables Farming and Farmer's Perception of Soil and Water Degradation in Two Periurban Areas in Yaounde Cameroon
}

\author{
Yvette Clarisse Mewouo Mfopou ${ }^{1,2}$, Mamadou Traore', Pierre Popice Nuemsi Kenmogne ${ }^{3}$, \\ Amina Aboubakar' ${ }^{2}$, Gaëlle Stévie Fatou Manguele², Suzanne Abeline Tetmoun Maboune², \\ Jules Remy Ngoupayou Ndam ${ }^{3}$, Zacharia Gnankambary ${ }^{1}$, Hassan Bismarck Nacro ${ }^{1}$
}

${ }^{1}$ Polytechnic University of Bobo-Dioulasso, Bobo-Dioulasso, Burkina Faso

${ }^{2}$ Institute of Agricultural Research for Development, Yaounde, Cameroon

${ }^{3}$ University of Yaoundé I, Yaoundé I, Cameroon

Email:mfopou201@yahoo.com,mfopou@gmail.com

How to cite this paper: Mfopou, Y.C.M., Traore, M., Kenmogne, P.P.N., Aboubakar, A., Manguele, G.S.F., Maboune, S.A.T., Ndam, J.R.N., Gnankambary, Z. and Nacro, H.B. (2017) Structure of Vegetables Farming and Farmer's Perception of Soil and Water Degradation in Two Periurban Areas in Yaounde Cameroon. Open Journal of Soil Science, 7, 333-346.

https://doi.org/10.4236/ojss.2017.711024

Received: October 12, 2017

Accepted: November 21, 2017

Published: November 24, 2017

Copyright $\odot 2017$ by authors and Scientific Research Publishing Inc. This work is licensed under the Creative Commons Attribution International License (CC BY 4.0).

http://creativecommons.org/licenses/by/4.0/

\section{c) (i) Open Access}

\begin{abstract}
Vegetable farming is an activity sensitive to the dynamism of the population and to the level of intensification in the use of soil resources. A study was conducted in the peri-urban zones of Yaoundé to present the socioeconomic characteristics of vegetable farming and the farmers' perception of soil and water degradation as a result of this activity. A semi-structured questionnaire was administered to this purpose in 2016 in two vegetable farming sites in Yaoundé, namely Nkolbisson and Nkolondom III. Results showed that most vegetable farmers from both sites (around 75\%) lack training in agriculture while 74 and 90 didn't benefit from training on management of pesticides. Spreading and landfilling of amendments are the two most popular ways of applying fertilizers. In fact, while the majority $(35.4 \%)$ of these fertilizers is applied at planting time, the minority $(4.9 \%)$ is applied several months before planting. Besides young plots are more exploited (52.4\% and 30\%) compared to older ones $(2.4 \%$ and $5 \%)$ in Nkolondom III and Nkolbisson respectively, as they are more responsive to fertilizer application. As consequence, high rates of fertilizers are applied to the oldest farms. As for irrigation water, it is altogether polluted. Base on the above, the farmers' perception of degradation is seen through the degradation of soils properties with time in the order of $14.3 \%$ to $60 \%$ and $15 \%$ to $44 \%$ at Nkolbisson and Nkolondom III respectively resulting in a gradual decrease of crop production (up to $50 \%$ ). It is also seen through the polluted produce obtained from irrigation and cleaning water.
\end{abstract}

\section{Keywords}

Soil, Water, Degradation, Vegetable Farming, Cameroon 


\section{Introduction}

Water and soil are important natural resources that play a prominent role in domestic activities and agricultural development in most African cities, the pressure on the use of these resources is constantly increasing due to the exponential increase of the population orchestrated by rural exodus. In this situation, the design of food stuff supply is modified in urban and peri-urban areas of Yaounde in Cameroon [1]. Vegetables are valued by the population; therefore vegetable farming is not only a source of food supply but also a source of employment in agricultural sector [2]. This activity is mainly located in swampy lowlands, slopes, roadsides with heavy pressure on space [3]. Vegetable farming reveals an interaction among the categories of actors, spaces types, crops species, the products obtained and the average incomes generated [4]. It thus constitutes one of the main economic activities on which the population depends. This type of agriculture is demanding in terms of soil fertility management and water supply. There is a significant investment in crop techniques, fertilizers used, and pesticides treatments to meet the ever-increasing demand throughout the year. The increasing demand for vegetable produces leads to an intensification of their production [5] aiming to high yields, which may negatively impact the preservation of water and soil resources [6]. This study aimed at having a better knowledge of the characteristics of the vegetable farming in Yaounde, Cameroon.

\section{Materials and Methods}

\subsection{The Study Sites}

The study was carried out in July 2016 at the Nkolbisson $\left(3^{\circ} 52^{\prime} \mathrm{N}\right.$ and $\left.11^{\circ} 27^{\prime} \mathrm{E}\right)$ and Nkolondom III $\left(3^{\circ} 57^{\prime} \mathrm{N}\right.$ and $\left.11^{\circ} 31^{\prime} \mathrm{E}\right)$ peri-urban vegetable farming sites, West and North of Yaounde respectively (Figure 1). Yaounde, the capital of Cameroon enjoys a rolling topography with dominant slope between 10 and $18 \%$. Steeper slopes $(25 \%-35 \%)$ occur locally whereas flatter tracts of land are found on small plateaus. The average annual rainfall among to $1600 \mathrm{~mm}$ and occurs in a bimodal configuration such that the first and second cropping seasons, separated by a 4-month dry season, last from mid-March to early July and from late August through mid-November respectively [7]. The duration of each of these seasons varies today and the rains in the second season are erratic due to global warming. The population of Yaounde was estimated in 2015 at 2.8 million [8].

The intertropical type of vegetation is observed in Yaounde with a predominance of humid forest. The city's hydrographic network is very diverse and consists mostly of streams, rivers and ponds. Apart from the hydromorphic soils located in the wetland, ferralitic soils predominate with good physical properties with internal drainage and good water retention capacity. These soils are acid with a low cation exchange capacity [9]. The lithological bedrock is essentially formed by the grenating gneisses. 


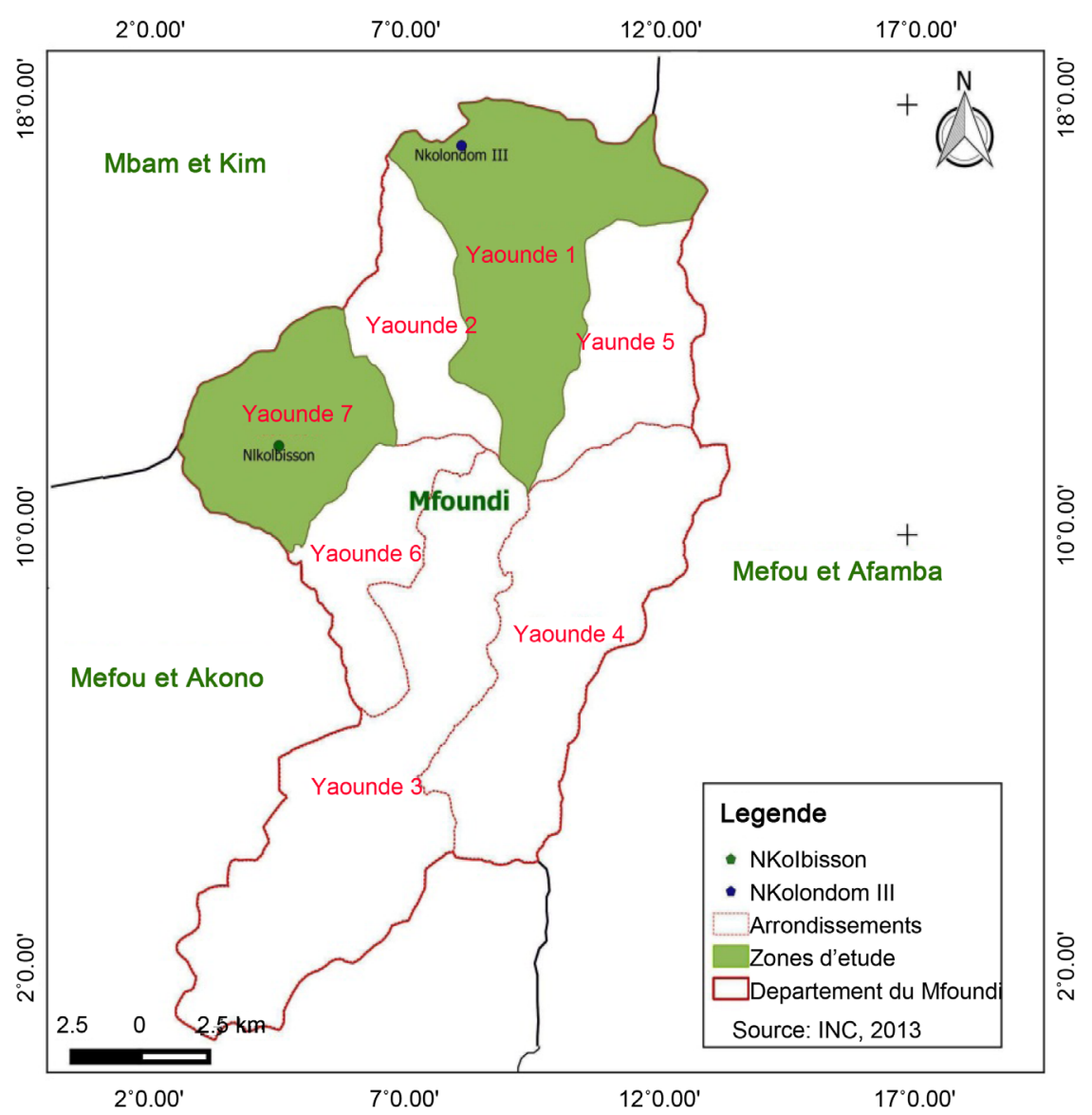

Figure 1. Geographical location of Nkolbisson and Nkolondom III sites.

\subsection{Data Collection and Analysis}

\subsubsection{Targeted Actors and Parameters Taken into Consideration}

The surveys were conducted during the month of July 2016 by using semistructured questionnaires as described by Sinarinzi and Nisabw [10]. A total of 100 permanent or seasonal farmers were surveyed with 50 interviewers per site. Using the knowledge of local residents who have been working on vegetable farming, list of all farmers in each village was generated. To select farmers, a cluster sampling strategy was adopted. Using this list as sampling frame, households were selected in each site using a simple random sampling technique (RAND function in Excel 2010). The households were sorted using the random numbers from lowest to highest and the first 50 households were used as the sample. The data collected concerned the socio-economic characteristics of the farmers (age, sex, educational level, training and ethnicity), the area and number of years of farming in the site, cultural practices associated with crop production and the training of farmers on the appropriate use of pesticides and water.

\subsubsection{Data Analysis}

The processing of data survey from vegetable farming was done using Cs-Pro 6.2, SPSS 20.0 and Excel 2010. 


\section{Results}

\subsection{Socio-Economic Characterization of Farmers}

\subsubsection{Repartition of Farmers by Gender and Age}

The results of surveys show that the farmers based at Nkolbisson and Nkolondom III sites were equal in the proportion of males to females (Figure 2) with age ranging between 30 and 60 years (Figure 3 ). In these sites and at Nkolbisson, the activities are executed by a majority of farmers aged between 30 and 60 (43\%) and 0 to 30 years (19\%) as compared with Nkolondom III where it occurs for farmers aged between 30 and 60 years (74\%) and above 60 years (53\%)

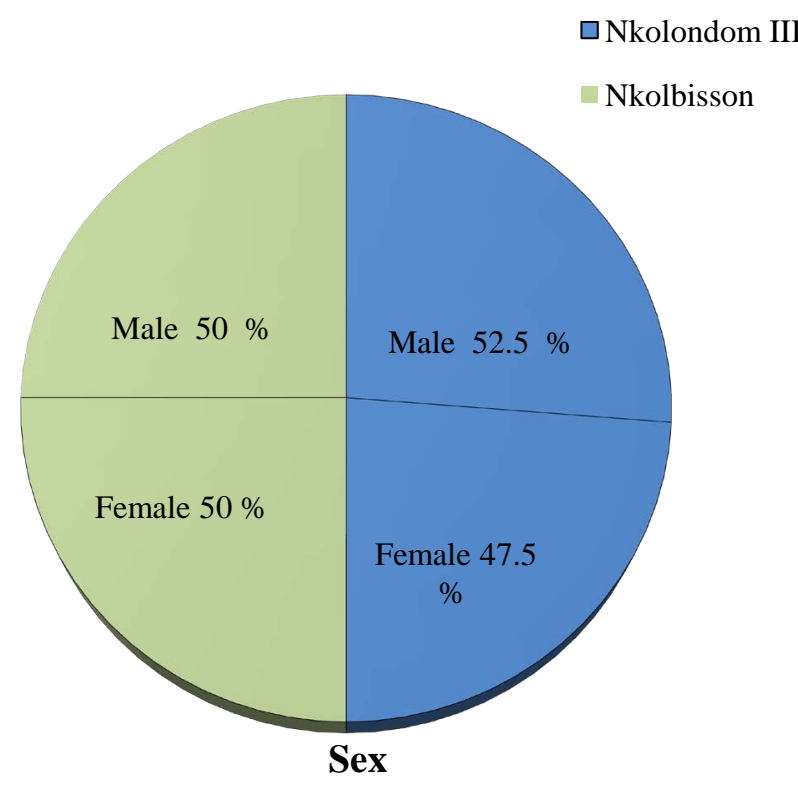

Figure 2. Repartition of farmers by gender at Nkolbisson and Nkolondom III.

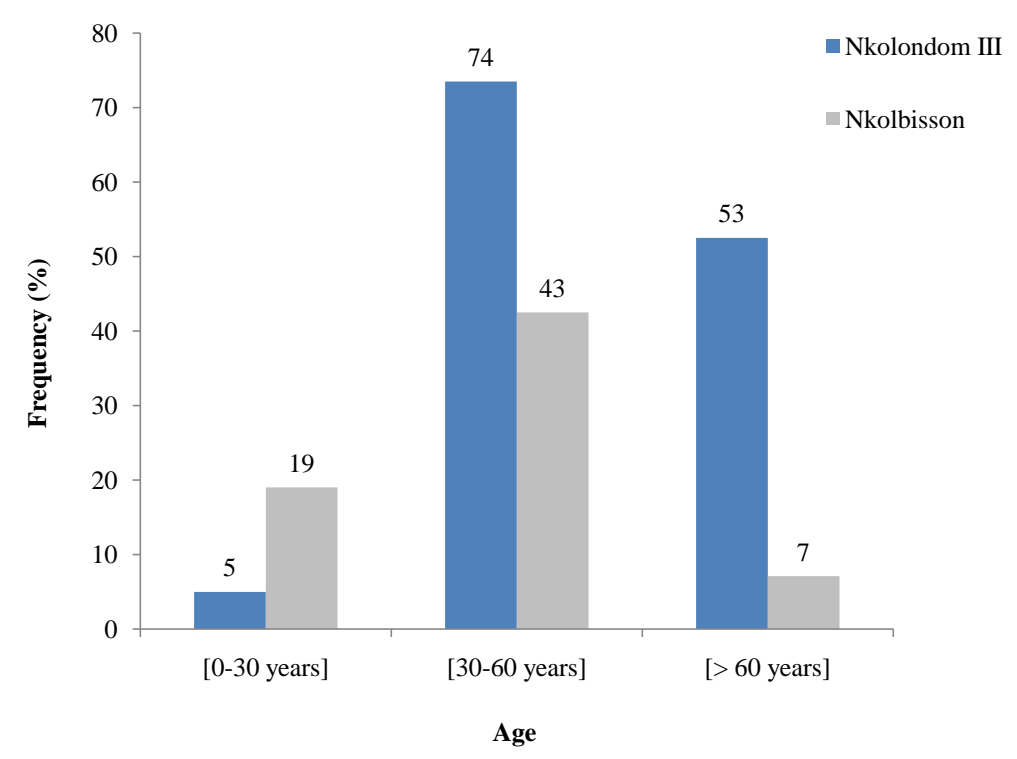

Figure 3. Repartition of farmers by age at Nkolbisson and Nkolondom III. 
(Figure 3). Therefore, farmers at Nkolbisson are younger than those at Nkolondom III. The frequency of farmers above 60 years at Nkolondom III is $45.4 \%$ higher than those of Nkolbisson site.

\subsubsection{Educational Level of Farmers}

Irrespective of the site, survey results show that farmers are grouped into four classes according to their level of education (Figure 4). There was vegetable farming with no formal education (literate), others with primary, or secondary or university levels. Literate farmers accounted for the smallest proportion (2.5\%), while those with secondary education constituted the largest proportion (43\%) in both sites. However it is worth noting, that 20 and $38 \%$ of farmers at Nkolbisson and Nkolondom III respectively (showing a gap of $18 \%$ between the two sites), have attained a university study level (students and teachers of teacher training schools) and therefore practice this activity on a seasonal basis. In general, the percentage of vegetable farming with at least a secondary school level is higher in Nkolbisson (81\%) as compared with Nkolondom III (63\%).

\subsubsection{Specific Training}

In the both vegetable farming sites, there are four main classes of specific training: general education and technical education, agriculture and livestock (Figure 5). In Nkolondom III, there exist a high proportion of vegetable farming with training in animal husbandry (45\%), while in Nkolbisson, those with technical education (35\%) constitute the highest proportion. To sum up, the percentage of vegetable farming with specific training in agriculture is low in both sites: $22 \%$ in Nkolbisson and $28 \%$ in Nkolondom III whit a difference of $6 \%$ between them.

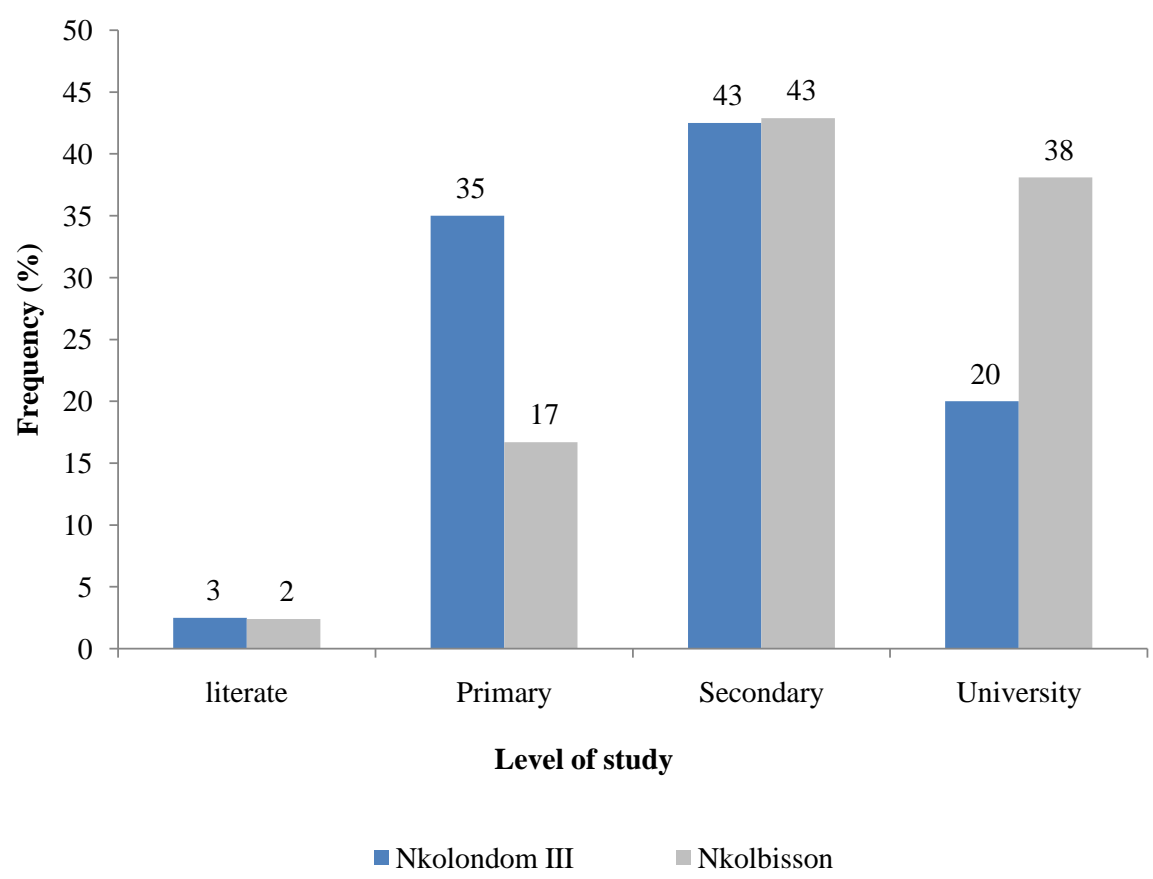

Figure 4. Educational level of farmers at Nkolbisson and Nkolondom III. 


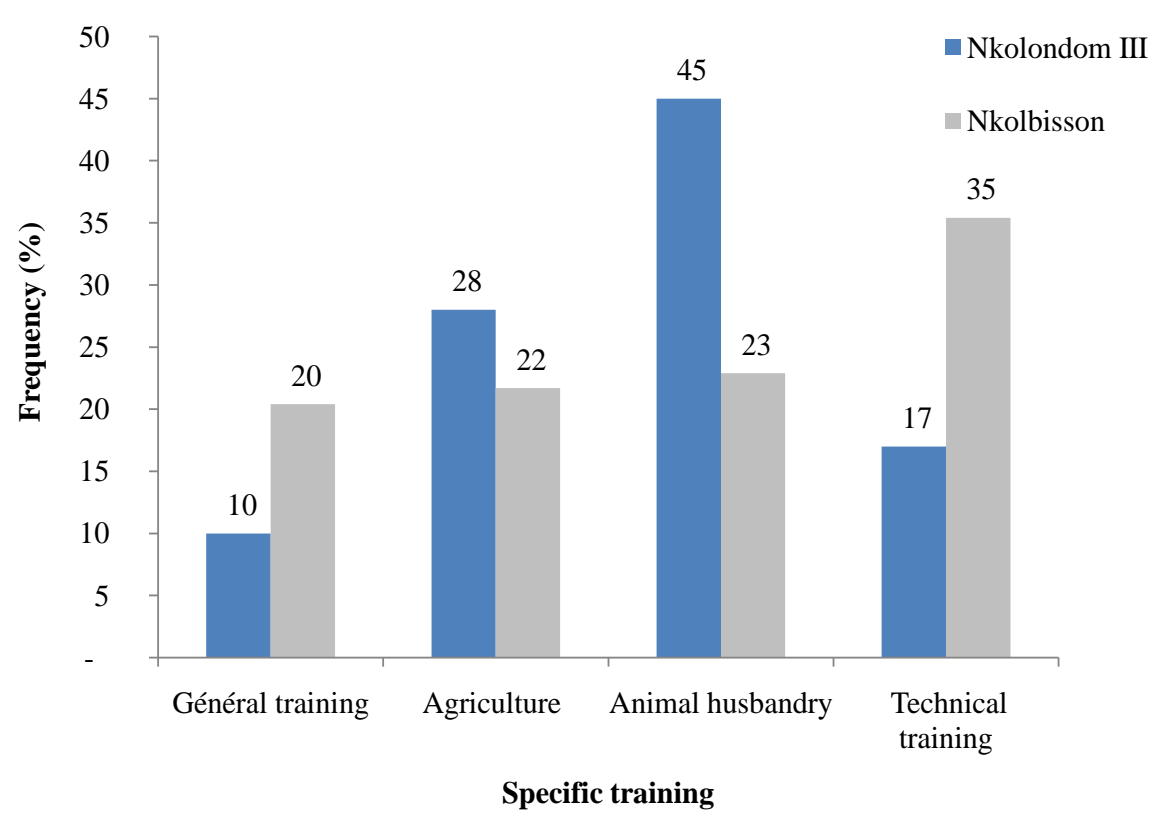

Figure 5. Specific training received by farmers at Nkolbisson and Nkolondom III.

\subsection{Level of Pressure on the Soils of Nkolbisson and Nkolondom III}

Different levels of pressure were observed on the soils of Nkolbisson and Nkolondom III. The frequency of farming exploitation of these soils at Nkolbisson varies according to the number of years they have been cultivated and the area occupied. It decreases drastically by $30 \%$ to $5 \%$. Plots under cultivation between 1 and 15 years are heavily exploited (80\%) compared to those of over 16 years of cultivation (20\%) (Figure 6). The same holds true for Nkolondom III where the frequency of farming of these plots also varies according to the number of years under use. The decrease was drastic in the other of $52.4 \%$ to $2.4 \%$. Similarly, soils under cultivation between 1 and 5 years are heavily exploited (52.4\%) compared with those of over 6 years of used (between 2.4 and 16.7\%) (Figure 6).

The over farming of soils is more observed on plots under cultivation between 1 and 15 years at Nkolbisson (80\%), whereas at Nkolondom III, it happens on plots between 1 and 5 years old (52.4\%). On the other hand, the over exploitation is low on plot with more than 16 years under cultivation in both sites. The percentage of over exploitation soils under cultivation between 1 and 5 years is 22.4\% higher at Nkolondom III than Nkolbisson site. In the contrary, this over activity is lower by $2.6 \%$ in Nkolondom III as compare to Nkolbisson in plots over 26 years under cultivation.

\subsection{Nature/Type of Fertilizers and Rate of Application}

The fertilizers and amendments used in the Nkolbisson and Nkolondom III vegetable farming were mostly chicken manure, crop residues, pig slurry and compound chemical fertilizer NPK. During these surveys, it appeared that farmers 

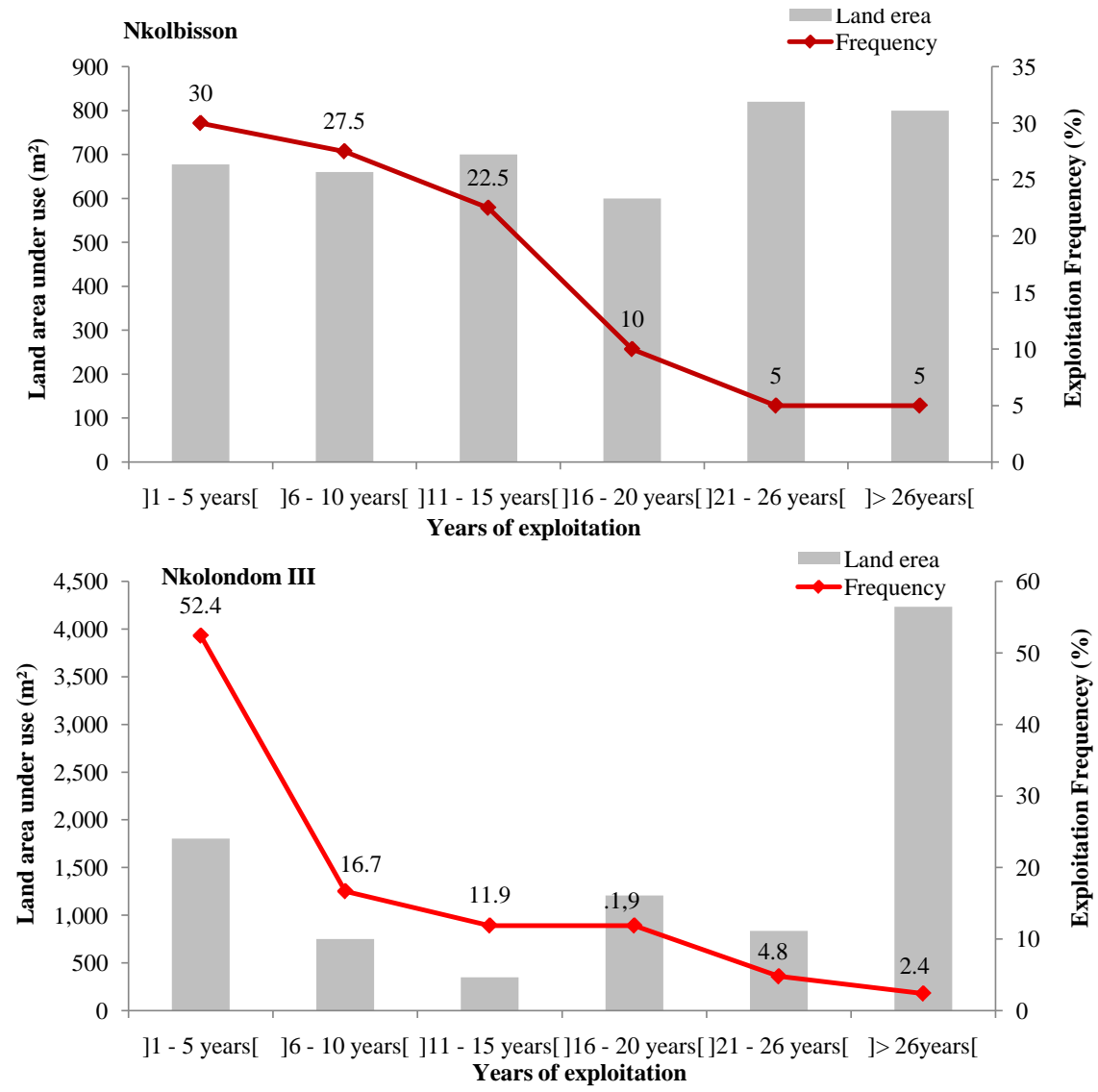

Figure 6. Level of pressure on the soil of vegetable farm of Nkolbisson and Nkolondom III.

derived the level of fertility from the time under cultivation. These farmers therefore apply fertilizers according to the age of the plots. That is, the older the plot (11 to 26 years), the more fertilizers it receives. Moreover, the quality of these fertilizers also varies according to the duration of exploitation. On plots used during 1 to 10 years, vegetable farming mostly apply chicken manure at an average rate of $4.5-6.66 \mathrm{~kg} / \mathrm{m}^{2}$, but NPK $20-10-10$ at a low rate of 0.03 to 0.20 $\mathrm{kg} / \mathrm{m}^{2}$ on average basis. There is a greater use of inputs on older farms (over 11 to 26 years). The rate of chicken manure applied on plots of more than 26 years old changed from simple to triple as compared to the one applied on younger plots with rates of $20 \%$ to $59 \%$ and $12 \%$ to $34 \%$ respectively in Nkolbisson and Nkolondom III. Therefore there is an increase of $8 \%$ and $29 \%$ from young to old plots respectively in Nkolbisson and Nkolondom III. The frequency of fertilizer application increases linearly with the age of the farms in both sites (Figure 7) and consequently, with high rates of NPK 201010 which might contribute not only to degradation but also to the pollution of these soils.

\subsection{Application of Fertilizers}

The two most common ways of fertilizer applications in Nkolbisson and Nkolondom III sites are by simple spreading and landfilling. These fertilizers are 


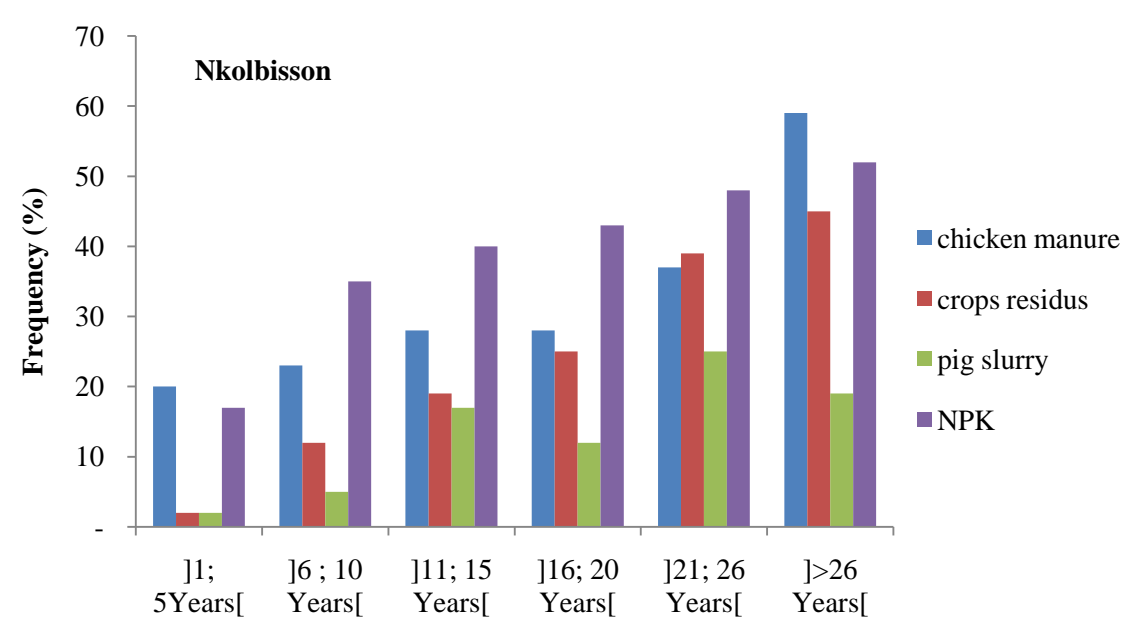

Years of exploitation

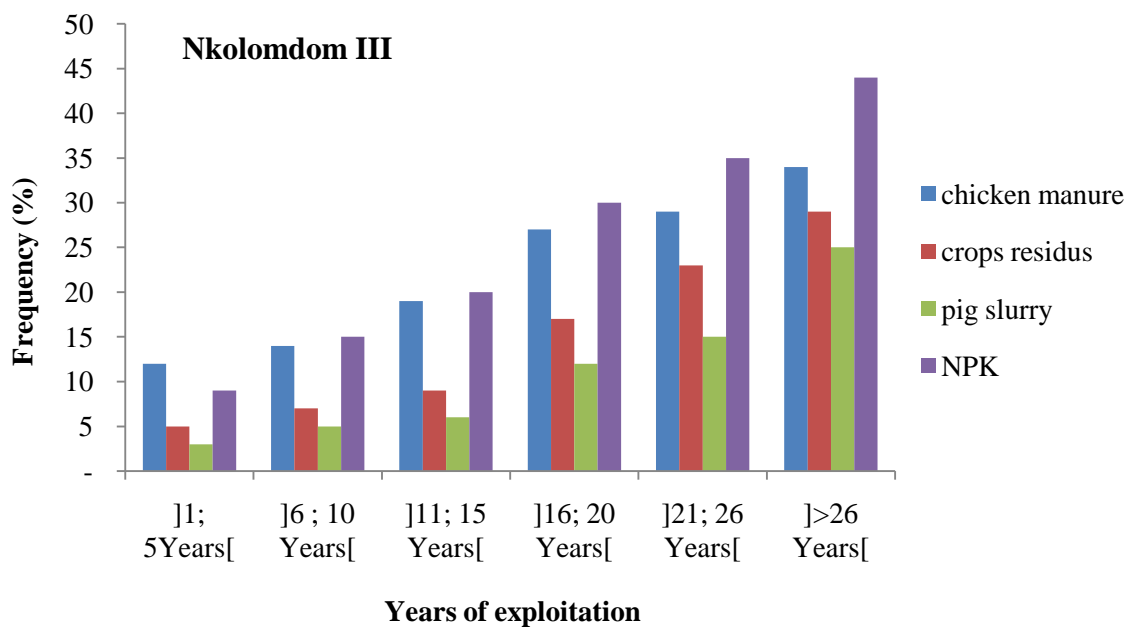

Figure 7. Nature/type of fertilizers and rate of application used in the Nkolbisson and Nkolondom III vegetable farming.

applied at $93 \%$ by simple spreading and $8 \%$ by landfilling at the Nkolondom III site (Figure 8). At Nkolbisson, only simple spreading is used for fertilizer application. In most cases $35.4 \%$ of these fertilizers are applied during planting, but in a few cases it is done at $4.9 \%$ several months before planting (Figure 9).

\subsection{Water Used for Irrigation in Vegetable Farming}

The irrigation water used by farmers in these areas comes mainly from streams. It is worth noting that in Nkolbisson water used to irrigate vegetables have a dual origin; where $40 \%$ are from small wells build near the plots and $60 \%$ from the streams (Figure 10). The water used to irrigate vegetables in Nkolbisson comes only from Abiergue stream which is highly polluted because it is the dumping ground for various excrement (human and animal waste), waste (garbage) and waste water from hospital, washing cars, motorcycles, harvested products, equipment used for the application of pesticides, as well as clothes and discarded dishes and traffic jam. Conversely, the irrigation water used in 


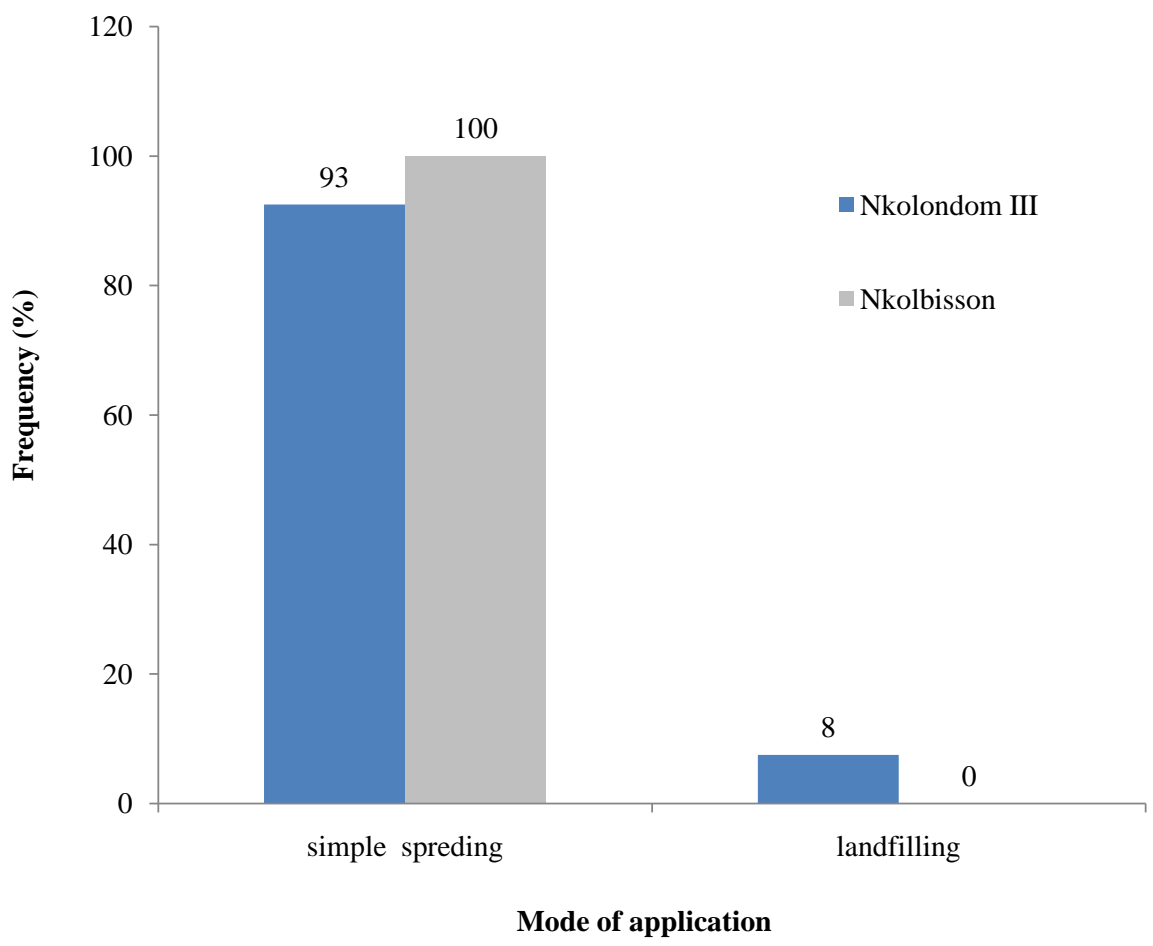

Figure 8. Mode of application of fertilizers by Nkolbisson and Nkolondom III farmers.

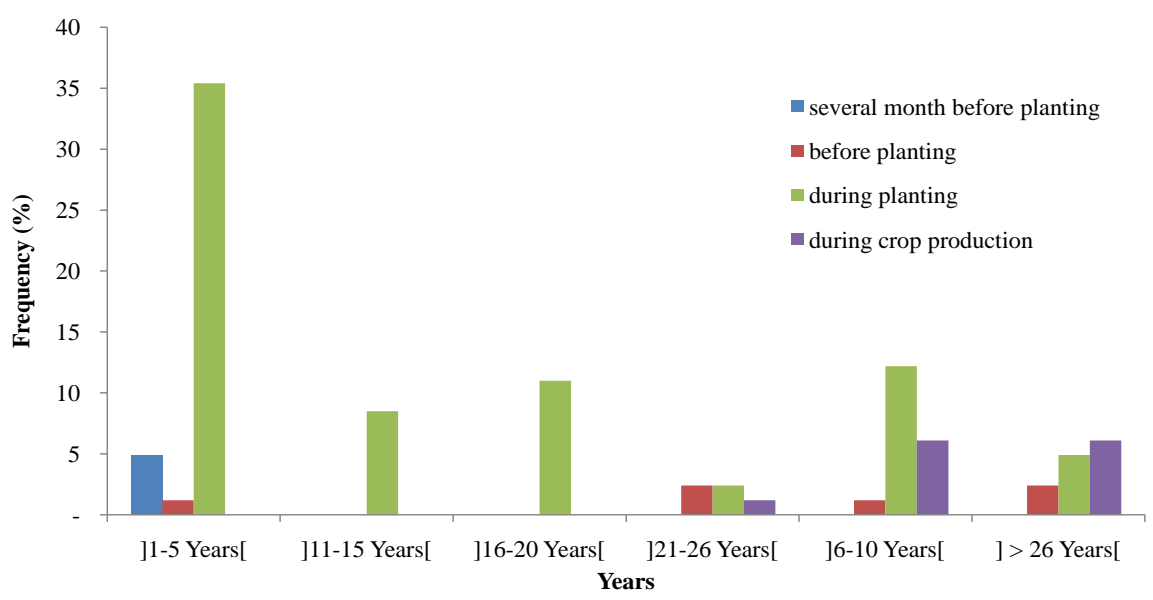

Figure 9. Time of application of fertilizers by Nkolbisson and Nkolondom III farmers.

Nkolondom III comes from the Kankouna River, which appears to be less polluted because human activities are less accentuated around and in this watercourse (only waste water from harvested products, equipment used for the application of pesticides, as well as clothes and discarded dishes).

\subsection{Application of Agricultural Pesticides}

Agricultural pesticides mainly insecticides and pesticides are applied at very high rates by farmers at the Nkolbisson and Nkolondom III sites. Most have not been trained (over than $74 \%$ in both sites) on the management of these products (Figure 11). 


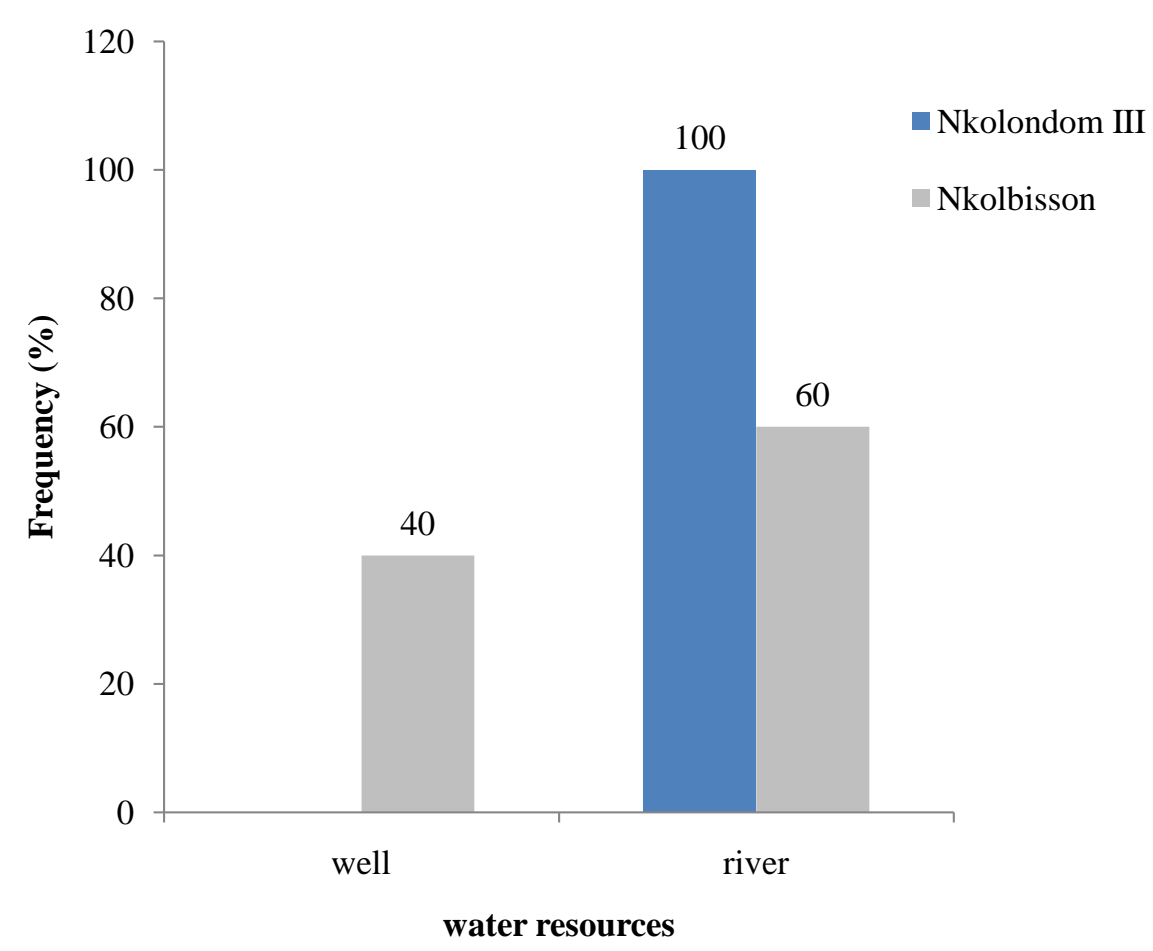

Figure 10. Water used for irrigation by Nkolbisson and Nkolondom III farmers.

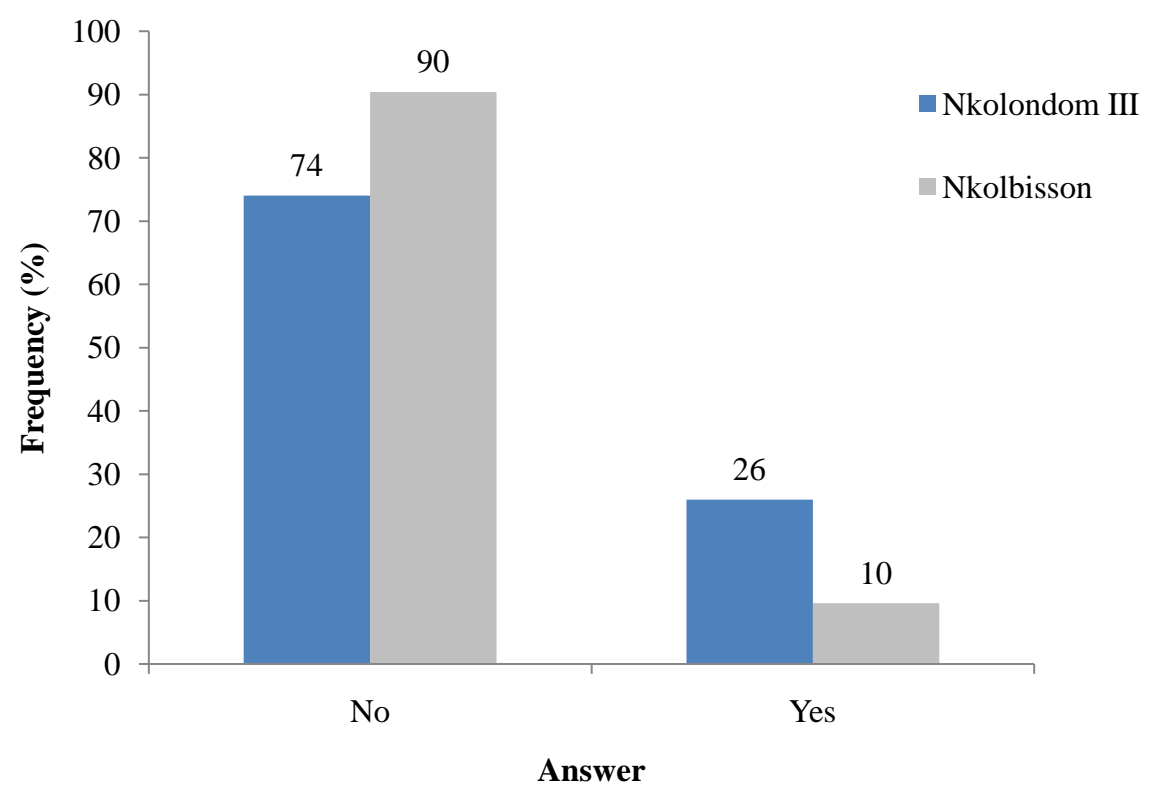

Figure 11. Application of agricultural pesticides by Nkolbisson and Nkolondom III farmers.

\subsection{Consequences of the Method of Fertilizer Application}

Fertilizer application is never done after soil analysis in both Nkolbisson and Nkolondom III sites, leading to several consequences ranging from improvement to degradation of soil structure according to the number of years of exploitation (Figure 12). There is a potential degradation of $4.5 \%$ to $50 \%$ and 

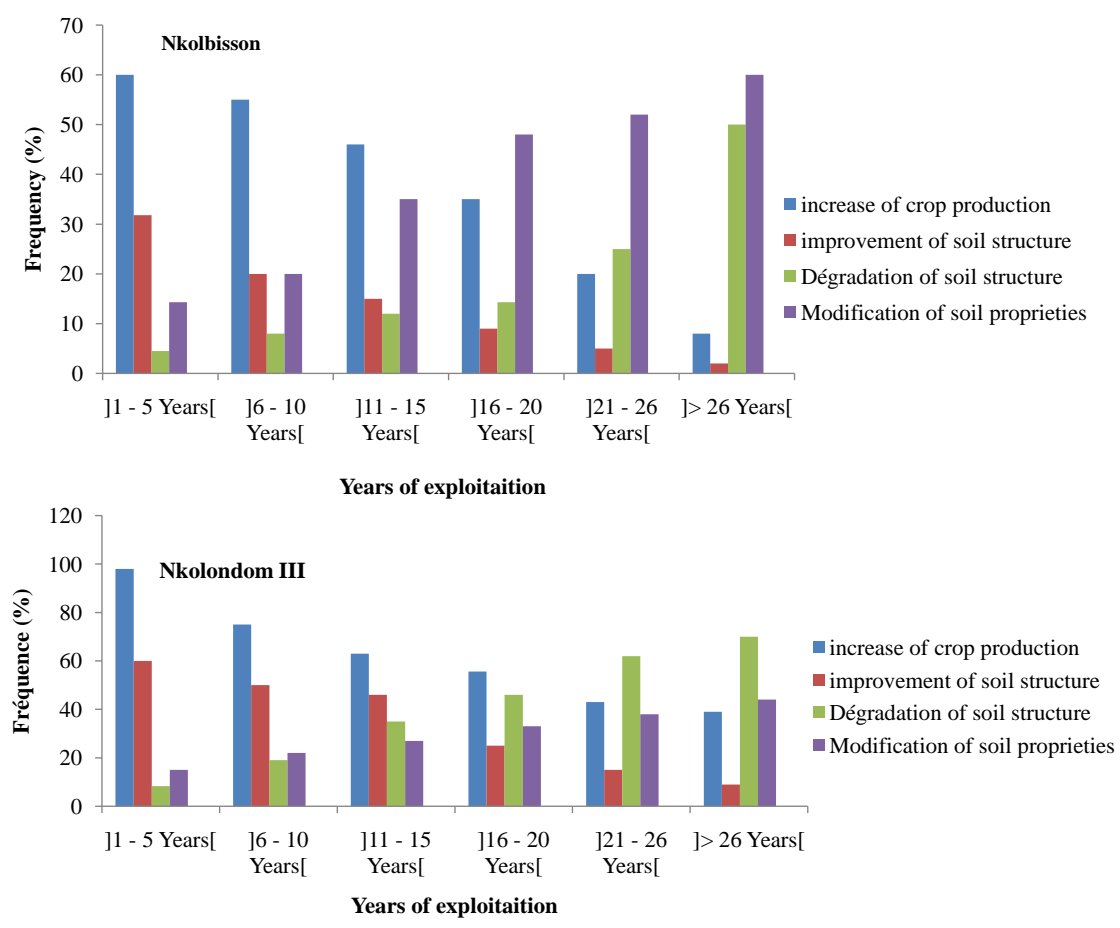

Figure 12. Consequences of the method of fertilizer application.

$8.3 \%$ to $70 \%$, as well as a change in soil properties in the range of $14.3 \%$ to $60 \%$ and $15 \%$ to $44 \%$ in Nkolbisson and Nkolondom III respectively. This worrying degradation coupled with the modification of soil properties is highly observed in plots of more than 26 years old at Nkolbisson, and above 16 years old at Nkolondom III. This degradation highlights the negative impact of the high use of chemical fertilizers on soil resources in these sites. A decline in crop production from $60 \%$ to $8 \%$ and $98 \%$ to $39 \%$ was observed and also the quality of the soil structure from $30.8 \%$ to $2 \%$ and $60 \%$ to $9 \%$ in the two sites (Figure 12). The decrease in agricultural production is higher (7\%) in Nkolondom III as compare to Nkolbisson.

\section{Discussion}

The socioeconomic data from the survey showed that farmers of the Nkolbisson and Nkolondom III sites are of equal proportion of men and women; Contrary to the trend observed in the Nkolbisson site in 2010 by Kouam and et al. [11] (percentage of men was superior of those of women). This situation may be due to urbanization, lack of jobs and dynamism of women who are now also conducting activities out of their homes. vegetable farming are mostly done at the Nkolbisson site by farmers age between 0 to 60 years while at Nkolondom III, it is carried out by those age over 30 years old.

Most vegetable farmers lack training in agriculture from both sites (around 75\%) at Nkolbisson and Nkolondom III. This could be explained by the "high" level of intensification of this activity exerted on these soils. Indeed, new plots are more exploited compared to old plots because farmers consider that the for- 
mer is more productive than the latter. This justifies the high rates of fertilizers applied on the older farms.

The fact that most $(74.03 \%$ and $90.38 \%$ at Nkolondom III and Nkolbisson respectively) farmers lack training on the application of chemicals products can be a major problem for health and the environment as raised by Kanda et al. [12]. Their level of education indicates a poor knowledge on the use of pesticides, their remanence, their degree of pollution and their limit of efficiency according to the movement of pests [13]. The level and type of training of farmers explain the regression of the frequency of exploitation of the soils according to the number of years under use. Thus, vegetable farming is practiced with techniques that are inadequate for sustainable production, which leads to a change in land use [14].

The continued and high rate applications of chemical fertilizers in vegetable farming increases the health, soil and water pollution risks [15]. This could result in the degradation of groundwater quality, soil structure and changes in physicochemical properties, thus significantly reducing their fertility [16].

Wastewater used in this agriculture increases the risk of food and groundwater pollution [11]. Results of this study show that, the wastewater used comes from the basins of Abiergué and Kankouna for Nkolbisson and Nkolondom III sites respectively. These waters are suspected to be loaded with pollutants, Fecal Coliforms, Fecal Streptococci [17], which is not in line with the guidelines prescribed by OMS [18]). Human activities will have to be reoriented in these areas in order to guarantee the nutrition and health of the populations.

\section{Conclusion}

Human activities which lead to soil and water degradation as observed by farmers are increasing in vegetable sites with increasing number of years of exploitation. The negative effect of this way of farming on the natural resources used could be due to the poor know how of the farmers on the management of pesticides. While the soil gets degraded as result of its intensive manipulation, the use of chemical fertilizer at high rates and contaminated water from Abiergue and Kankouna polluted streams modifies soil physicochemical properties, then leading to the reduction of sustainable soil fertility.

\section{Acknowledgements}

The present work was partially supported by CORAF/WECARD project 03/PA/05 and the International Foundation for Science (IFS), Sweden, through research grants to Yvette Clarisse MFOPOU MEWOUO (Ref. N/: W/5004-1). We also thank members of Laboratory of Soil, Plant, Water and Fertilizer (LASPEE) of the Institute of Agricultural Research for Development (IRAD) for their collaboration. We appreciate the material assistance obtained from IRAD Cameroon during this work. We also thank Delphine Lamare and Mike Akem for all their contributions. 


\section{References}

[1] Bhan, S. (2013) Land Degradation and Integrated Watershed Management in India. International Soil and Water Conservation Research, 1, 49-57. https://doi.org/10.1016/S2095-6339(15)30049-6

[2] Tshomba, K.J., Nyembo, M.L., Ntumba, N.F., Mushagalusa, B.A., Muyambo, M.E., and Nkulu, M.F.J. (2015) The Functions of Market Gardening in the Socio-Economic Context of Lubumbashi in DR Congo. International Journal of Innovation and Applied Studies, 11, 291-302.

[3] Yolou, I. (2016) Activité de maraîchage en milieu à Parakou au Nord-Bénin: Caractéristiques et problemsfonciers. International Journal of Innovation and Applied Studies, 14, 1086-1095.

[4] Nguegang A.P. (2008) L'agriculture urbaine et périurbaine à Yaoundé : analyse multifonctionnelle d'une activité montante en économie de survie. Thèse de doctorat, Universite libre de Bruxelles, 200 p.

[5] Prathiba and Rani, S. (2012) Nutrition Gardening-A Venture to Mitigate Malnutrition. Abstracts. Global Conference on Horticulture for Food, Nutrition and Livelihood Options, Bhubaneswar, 28-31 May 2012, 11-12.

[6] Gruhn, P., Golleti, F. and Yudelman, M. (2000) Integrated Nutrient Management, Soil Fertility and Sustainable Agriculture: Current Issues and Future Challenges. International Food Policy Research Institute. Food, Agriculture and Environment Discussion Paper 32, Washington DC.

[7] Ambassa-Kiki, R. and Nill, D. (1999) Effects of Different Land Management Techniques on Selected Topsoil Properties of a Forest Ferralsol. Soil and Tillage Research, No. 59, 259-264. https://doi.org/10.1016/S0167-1987(99)00067-7

[8] Anonyme (2015) https://fr.wikipedia.org/wiki/Yaoundé

[9] Ambassa-Kiki, R., Tchienkoua, M. and Agoume, V. (1995) Site and Soil Characterization Report. In: Ambassa-Kiki, R., Ed., Land Clearing on Acid Soils in Forested Regions in Central Cameroon, JRA/IB SRAM, Yaoundé, 14-27.

[10] Sinarinzi, F. and Nisabw, T. (1999) Étude sur la problématique des terres laissées par les réfugiés de 1972 dans les communes Rumonge et Nyanza-Lac, Bujumbura, Burundi, $42 \mathrm{p}$.

[11] Kouam, K.G.R., Rosillon, F., Mpakam, H.G. and Nono, A. (2010) Enjeux sanitaires, socio-économiques et environnementaux liés à la réutilisation des eaux usées dans le maraîchage urbain : cas du bassin versant de l'Abiergué (YaoundéCameroun). Vertigo, $10,1-21$.

[12] Kanda, M., Wala, K., Batawila, K., Djaneye-Boundjou, G., Ahanchédé, A. and Akpagana, K. (2009) Le maraîchage périurbain à Lomé : pratiques culturales, risques sanitaires et dynamiques spatiales. Cahiers Agricultures, 18, 356-363.

[13] Madjouma, K., Gbandi, D., Kpérkouma, W., Kissao, G., Komlan, B., Ambaliou, S. and Koffi, A. (2013) Application des pesticides en agriculture maraichère au Togo. Vertigo-la revue électronique en sciences de l'environnement, 13, 1-19.

[14] Bamba, I., Mama, A., Neuba, D.F.R., Koffi, K.J., Traoré, D., Visser, M., Sinsin, B., Lejoly, J. and Bogaer, T.J. (2008) Influence des actions anthropiques sur la dynamique spatio-temporelle de l'occupation du sol dans la province du Bas-Congo (R.D. Congo). Sciences \& Nature, 5, 49-60. https://doi.org/10.4314/scinat.v5i1.42151

[15] Tano, B.F., Abo, K., Dembele, A. and Fondio, L. (2011) Systèmes de production et pratiques à risque en agriculture urbaine : cas du maraîchage dans la ville de 
Yamoussoukro en Côte d'Ivoire. International Journal of Biological Chemical Science, 5, 2317-2329.

[16] Jaouad El, A., Sanae, K., Namira El, A., and Abderrauf, H. (2007) Impact des activités anthropiques sur la qualité des eaux souterraines de la communauté mzamza (chaouIa, maroc). Journal of Water Science, 20, 309-321.

[17] Mfopou Mewouo, Y.C., Noah Ewoti, O.V., Aboubakar, A., Ndjama, J., Ndam N-goupayou, J.R., Nola, M., Ekodeck, G.E., Zebaze Togouet, S.H. and Bilong, P. (2014) Mi-Crobiological Quality of Shallow Irrigation Water at Nkolbisson a Sub-Urban Area of Yaounde (Cameroon): Influence of Some Physicochemical Properties. International Journal of Research in Earth \& Environmental Sciences, 2. 8-17.

[18] OMS (1989) L'utilisation des eaux usées en agriculture et en aquaculture : recommandations à visées sanitaires. Rapport d'un groupescientifique de l'OMS, OMS, Genève, $74 \mathrm{p}$. 